Effect of Rhizospheres Bacteria Isolated from Kahramanmaraş Pepper Fields Against Phytophthora capsici

\author{
Zeynep Hümeyra ARDIÇ1, Mustafa KÜSEK2 ${ }^{2}$, Ceyda CEYHAN3 \\ ${ }^{1}$ Adana Biyolojik Mücadele Araştırma Enstitüsü Müdürlüğü, Kışla Caddesi, 01321, Yüreğir/ADANA, 2,3Kahramanmaraş Sütçü İmam \\ Üniversitesi, Ziraat Fakültesi, Bitki Koruma Bölümü, Kahramanmaraş \\ ${ }^{1}$ https://orcid.org/0000-0002-6195-6351, ${ }^{2}$ https://orcid.org/0000-0002-6320-5869, ${ }^{3}$ https://orcid.org/0000-0002-9695-281X \\ $\square$ : mkusek@ksu.edu.tr
}

\section{ABSTRACT}

For the study, 36 soil samples with roots parts were taken from root zone of better grown healthy pepper plants from the pepper fields of Kahramanmaras province. Bacterial isolations were made from collected soil samples. Overall, 713 isolates were obtained from the bacteria colonies based on the morphological characteristics differences. By measuring the radius of inhibition zone, ZHA17 was determined to be most effective isolate. Fifteen isolates were selected from these bacteria in such a way to establish a zone to inhibit the growth of Phytophthora capsici and used in pot experiments under controlled conditions. The isolates were identified as Bacillus pumilus, $B$. subtilis ss subtilis, Mycobacterium confluentis, $M$. immunogenum, Paenibacillus castaneae, Pseudomonas fluorescens, $P$. viridilivida and Tsukamurella paurometabola bacteria species according to Biolog GEN III identification system.

\section{Research Article}

$\begin{array}{ll}\text { Article History } & \\ \text { Received } & : 13.03 .2020 \\ \text { Accepted } & : 09.07 .2020\end{array}$

Keywords

Pepper

Soil Bacteria

Biolog Gen III

Phytophthora capsici

Biological Control

\title{
Kahramanmaraş Biber Alanlarından İzole Edilen Toprak Bakterilerinin Phytophthora capsiciye Karşı Etkisinin Belirlenmesi
}
ÖZET
Kahramanmaraş ilindeki biber ekim alanlarındaki biber bitkilerinden daha iyi gelişmiş sağlıklı bitkiler seçilerek kök bölgelerinden köklerle birlikte 36 toprak örneği alınmıştır. Bu toprak örneklerinden bakteri izolasyonu yapılarak elde edilen bakteri kolonilerinden morfolojik karakter farklılıkları göz önüne alınarak 713 izolat elde edilmiştir. Engelleme zonlarının yarıçapları ölçülmek suretiyle en etkili izolatın ZHA17 olduğu belirlenmiştir. Phytophthora capsicıye karşı bu bakterilerden engelleme zonu oluşturan 15 izolat seçilerek saksı çalışmasında kullanılmıştır. Saksı çalışmasında ZHA57, ZHA88, ZHA178, ZHA212, ZHA215, ZHA287 ve ZHA579 izolatları kök boğazı yanıklığı hastalığının gelişimini engellemiştir. Biolog Gen III tanılama sistemine göre izolatlar Bacillus pumilus, Bacillus subtilis ss subtilis, Mycobacterium confluentis, Mycobacterium immunogenum, Paenibacillus castaneae, Pseudomonas fluorescens, Pseudomonas viridilivida ve Tsukamurella paurometabola bakteri türleri olduğu belirlenmiştir.

\section{Araştırma Makalesi}

Makale Tarihçesi
Geliş Tarihi $\quad: 13.03 .2020$
Kabul Tarihi

Anahtar Kelimeler

Biber

Toprak Bakterileri

Biolog Gen III

Phytophthora capsici

Biyolojik Kontrol

To Cite : Ardıç ZH, Küsek M, Ceyhan C 2021. Effect of Rhizospheres Bacteria Isolated from Kahramanmaraş Pepper Fields Against Phytophthora capsici. KSU J. Agric Nat 24 (1): 70-75. https://doi.org/10.18016/ksutarimdoga.vi.702589.

\section{INTRODUCTION}

Many disease and pests lead to significant economic losses in pepper. Phytophthora capsici Leon., which is the agent causing the root-crown rot disease (Phytophthora blight of pepper), is one of the major diseases affecting pepper. The disease agent is seen at almost anywhere around the world, where pepper is grown, and leads to significant losses. It was detected on pepper in New Mexico for the first time in the world; and then the presence of the agent was reported all around the world. P. capsici was detected in Marmara, Aegean, Mediterranean, Black Sea, Central Anatolia and Southeastern Anatolia regions of Turkey leading to significant yield losses (Abak and Pitrat, 1981; Leonian, 1922). Phytophthora is a genus in Oomycota group and contains pathogens, which cause epidemics on many plants from time to time. There are more than fifty species of Phytophthora, which cause disease on 
plants (Tsao, 1983).

Biological control studies have distinct importance in controlling the diseases, which have no chemical control such as Phytophthora. It is known that certain bacteria and fungus in saprophytic character living on the rhizosphere zone of the plant are competitive and that they produce certain metabolic material so as to make repressive impact on the pathogenic agents. These include microorganisms such as fluorescent Pseudomonas, Bacillus, Trichoderma, Gliocladium, Taloromyces and avirulent Fusarium. Such microorganisms was started to be produced commercially due to their adaptation to the existing ecosystem and their positive effects on the plant growth.

In this study, beneficial bacteria isolates were recovered from the rhizosphere of healthy pepper plants in areas where crown rot disease is observed in the Kahramanmaras province and the antagonistic species were determined through in vitro tests and pot experiments under controlled conditions.

\section{MATERIAL and METHODS}

\section{The bacteria and fungi strains}

Bacteria isolates were isolated from the soil around the root zone of the pepper plants grown in the Kahramanmaras province. In order to isolate the bacteria, the soil samples were taken from the pepper plants with a good growing trend from a depth of 15-20 $\mathrm{cm}$ together with the root parts. The dilution series of the isolates, which was isolated from the soil, were prepared according to Aysan et al. (2003). The planting was made into Petri dishes containing Nutrient Agar (NA) nutrient media taking $100 \mu \mathrm{l}$ with the help of a glass stirrer from $10^{3}, 10^{5}$ and $10^{7}$ dilution series. At the end of 2-4 days incubation of the Petri plates in $25^{\circ} \mathrm{C}$, different colonies, which have developed in the NA nutrient media, were taken and pure cultures were developed on NA nutrient media.

The agent of the stem and fruit blight of peppers, $P$. capsici was obtained from the Eastern Mediterranean Transitional Zone Research Institute (Kahramanmaraş).

Determination of the effects of the bacterial isolates against $\mathrm{P}$. capsici

Phytophthora capsici isolate was planted on a disk area at a radius of $6.0 \mathrm{~mm}$ in the middle of a Petri dish containing HRA nutrient media. After planting the $P$. capsici isolate, different bacterial isolates were planted in spots with a toothpick at four sides of the isolate with a distance of $3 \mathrm{~cm}$ at each side. On the other hand, sterile water was used at the control treatment instead of bacteria. The development radius of the fungus in control and bacterial treatments was measured with a ruler on the $6^{\text {th }}$ day of planting. In order to identify the inhibition zone, colony radius length of the fungus in bacterial treatment was deducted from the colony radius length of the fungus in control application. This experiment was established according to the randomized trial design of four replication.

\section{Identification of the bacteria isolates}

Fifteen bacteria isolates selected according to the length of the inhibition zone were identified. Identification was made according to Anonymous (2008) and Rosvid et al. (2011) using Biolog GEN III MicroPlate (BIOLOG 21124 Cabot Blvd Hayward, CA 94545).

\section{Biological control in pot experiment}

In order to determine the efficiency of 15 isolates, which were isolated from the soil and selected according to their antagonistic effects against $P$. capsici in the growth chamber, a pot trial was established with the pepper seedlings in five repetitions. The density of the bacteria isolates, which were developed at $25^{\circ} \mathrm{C}$ in NA nutrient medium for a period of 24 hours, was adjusted to a concentration of $10^{8} \mathrm{cell} / \mathrm{ml}$ with physiologic water $(0.85 \% \mathrm{NaCl})$. Then the roots of the pepper plants were merged into suspension of bacteria isolates and awaited in such suspension for a period of 10 minutes and then transferred into the pots. However for the control application, the pepper seedlings were kept in physiologic water without bacteria for a period of 10 minutes and then transferred into the pots. P. capsici mycelium was inoculated into the peat until one petri plate $(10 \mathrm{~cm})$ was filled. The developing micelles were mixed to 11 torf and 1 petri dish. The plants, which were tranfered into the pots, were grown in climate chamber at $25^{\circ} \mathrm{C}$. The scalds on the stem was measured with a ruler 5 days after bacteria treatment. The results were compared by Duncan's Multiple Range Test at 5\% importance level.

\section{RESULTS}

\section{The effect of the soil bacteria against $P$. capsici}

During the study, 713 bacteria were isolated from the soil around the root zone of pepper plant. Fifteen isolates having the highest inhibition zone were selected among the isolates isolated from the soil. The inhibition zone of the selected bacteria varied between $17 \mathrm{~mm}$ and $29 \mathrm{~mm}$. ZHA212 isolate $(29 \mathrm{~mm})$ was found to have the highest inhibition zone, and followed by ZHA17 $(24 \mathrm{~mm})$, ZHA90 $(23.2 \mathrm{~mm})$ and ZHA296 (23 $\mathrm{mm})$ respectively. ZHA579 $(17 \mathrm{~mm})$, ZHA215 (17.3 $\mathrm{mm})$ and ZHA191 $(18 \mathrm{~mm})$ were observed to have the lowest inhibition zone among the selected isolates. All the selected bacterial isolates were found to be negative in the tobacco hypersensitivity reaction and pectolytic activity in potatoes. 
Identification of the bacteria isolates via BIOLOG identification system

The metabolic profiles of the selected bacteria were obtained using Biolog's Microbial Identification System Software program. The metabolic profiles of fifteen bacteria isolates, which were selected according to their zone radius, were identified according to the isolates with their metabolic profiles present in the system library. Two of the bacteria isolates were identified as Mycobacterium immunogenum (similarity rates of ZHA17 and ZHA57 isolates were $50 \%$ and $56 \%$ respectively); 5 isolates were identified as Paenibacillus castaneae (similarity rates of ZHA88, ZHA178, ZHA212, ZHA215 and ZHA296 isolates were $54 \%, 67 \%, 67 \%, 68 \%$ and $64 \%$ respectively); 1 isolate was identified as Bacillus pumilus (similarity rate of ZHA90 isolate was identified as 51\%); 1 isolate was identified as Pseudomonas fluorescens (similarity rate of ZHA91 isolate was 58\%); 1 isolate was identified as Mycobacterium confluentis (similarity rate of ZHA246 isolate was 51\%); 1 isolate was identified as B. subtilis ss subtilis (similarity rate of ZHA287 isolate was $68 \%$ ); 1 isolate was identified as $P$. viridilivida (similarity rate of ZHA308 was 63\%) and 1 isolate was identified as Tsukamurella paurometabola (similarity rate of ZHA569 isolate was 50\%) (Table 1). Two of the abovementioned bacteria didn't show similarity with the bacteria recorded on BIOLOG GEN III system.

\section{Biological control in pot experiments}

It was detected in pot experiments that ZHA57, ZHA88, ZHA178, ZHA296, ZHA308 and ZHA569 isolates, which were obtained from the bacteria isolated from the soil, inhibit development of Phytophthora blight of pepper significantly $\left(\mathrm{F}_{4,84}=\right.$ 9,$30 ; \mathrm{p}<0.05$ ) (Table 2).

Table 1 The bacteria isolates identified with Biolog GEN III automatic identification system.

Cizelge 1. Biolog GEN III otomatik tanılama sistemi ile tanılanan bakteri izolatları

\begin{tabular}{lll}
\hline $\begin{array}{l}\text { Species of the Bacteria } \\
\text { Bakteri Türü }\end{array}$ & $\begin{array}{l}\text { Similarity } \text { Rate (\%) } \\
\text { Benzerlik Oran1 }\end{array}$ & $\begin{array}{l}\text { Isolate Number } \\
\text { Izolat No }\end{array}$ \\
\hline Bacillus pumilus & 51 & ZHA90 \\
Bacillus subtilis ss subtilis & 68 & ZHA287 \\
Mycobacterium confluentis & 51 & ZHA246 \\
Mycobacterium immunogenum & $50-56$ & ZHA17, ZHA57 \\
Paenibacillus castaneae & $54-68$ & ZHA88,ZHA178,ZHA212,ZHA215,ZHA296 \\
Pseudomonas fluorescens & 58 & ZHA191 \\
Pseudomonas viridilivida & 63 & ZHA308 \\
Tsukamurella paurometabola & 50 & ZHA569 \\
Non-identified & & ZHA235, ZHA579 \\
\hline
\end{tabular}

Table 2 Effect of Rhizobacteria on development of the disease Cizelge 2. Rhizobacteriaların hastalık gelişimi üzerine etkisi

\begin{tabular}{|c|c|c|}
\hline $\begin{array}{l}\text { Isolates } \\
\text { Izolatlar } \\
\end{array}$ & $\begin{array}{l}\text { Length of the necrosis (cm) } \\
\text { Nekroz Uzunluğu (cm) }\end{array}$ & $\begin{array}{l}\text { Species of the Bacteria } \\
\text { Bakteri Türü }\end{array}$ \\
\hline $\begin{array}{l}\text { Negative Control } \\
\text { (Negatif Kontrol) }\end{array}$ & $00.0 \quad \mathrm{a}$ & \\
\hline $\begin{array}{l}\text { Positive Control } \\
\text { (Pozitif Kontrol) }\end{array}$ & 10.0 & \\
\hline ZHA246 & 10.0 & Mycobacterium confluentis \\
\hline ZHA235 & 10.0 & Unidentified \\
\hline ZHA90 & 10.0 & Bacillus pumilus \\
\hline ZHA17 & 09.1 & Mycobacterium immunogenum \\
\hline ZHA212 & 08.9 & Paenibacillus castaneae \\
\hline ZHA215 & 08.6 & Paenibacillus castaneae \\
\hline ZHA287 & 08.3 cde & Bacillus subtilis ss subtilis \\
\hline ZHA579 & 08.0 bcde & Unidentified \\
\hline ZHA191 & 07.8 bcde & Pseudomonas fluorescens \\
\hline ZHA308 & 07.3 bcd & Pseudomonas viridilivida \\
\hline ZHA178 & 06.9 bcd & Paenibacillus castaneae \\
\hline ZHA57 & $06.6 \mathrm{bcd}$ & Mycobacterium immunogenum \\
\hline ZHA569 & $06.5 \mathrm{bcd}$ & Tsukamurella paurometabola \\
\hline ZHA296 & 06.0 bc & Paenibacillus castaneae \\
\hline ZHA88 & $05.5 \mathrm{~b}$ & Paenibacillus castaneae \\
\hline
\end{tabular}


It was observed that ZHA17, ZHA212, ZHA215, ZHA287 and ZHA579 isolates inhibited Phytophthora blight of pepper partly, but such inhibition was not significantly important statistically. ZHA246, ZHA235 and ZHA90 isolates among the soil bacteria gave the same result with positive control and they were unable to inhibit development of the disease.

\section{CONCLUSION and DISCUSSIONS}

Rhizosphere soil samples were taken from 36 different pepper fields in Kahramanmaras province in order to isolate antagonistic bacterial agents, which may be used for biological control against P. capsici. Bacteria isolates. With this purpose a total of 713 bacterial isolates were obtained from the soil samples. An inhibition zone was determined against $P$. capsici in Petri plates on nutrient media for the rhizosphere bacteria isolates wherein 15 isolates which formed the greatest inhibition zone, were identified and these isolates were further tested in pot experiments. When the radius of the inhibition zones were examined 6 days after inoculation of the Rhizobacteria and the fungal pathogen together in Petri plates, the greatest inhibition zone was observed for Paenibacillus castaneae ZHA212 (29 $\mathrm{mm})$ and Mycobacterium immunogenum ZHA17 (24 mm) isolates; and the smallest inhibition zone was observed for ZHA579 (17 $\mathrm{mm}$ ) isolate, whose type could not be identified. Ling et al. (2014) reported that the efficiency of Paenibacillus spp. could be increased on terra rossa through different fertilization regimes and hence the number of the soil borne pathogens could be decreased through encouragement of the plant growth. Some species of Paenibacillus genus wereidentified as nitrogen fixing species (Anand and Chanway, 2013; Anand et al., 2013). They prevent germination and development of the plant pathogens on the soil; and hence they contribute soil productivity and plant health as they may be used for biological control (Ling et al., 2011; Gua and Liao, 2013).

Efficiency of the soilborne bacteria isolates against $P$. capsici were also reported in previous studies (Jee et al., 1988; Akgül and Mirik, 2008; Kim et al., 2009). Jee et al. (1988) observed Trichoderma harzianum, Pseudomonas cepacia and Bacillus polymyxa species forming an inhibition zone against Phytophthora capsici during their study.

Analyzing the results of Biolog Gen III identification system, 9 of the 15 isolates matched with different bacteria species (B. pumilus, B. subtilis ss subtilis, $M$. confluentis, $M$. immunogenum, Paenibacillus castaneae, $\quad$. fluorescens, $P$. viridilivida, Tsukamurella paurometabola) and 2 isolates (ZHA235, ZHA579) could not be identified. The highest similarity rate was observed as $68 \%$ between ZHA287 and $B$. subtilis ss subtilis.

In pot experiment conducted in order to determine the efficiency of the 15 isolates selected against $P$. capsici, $M$. immunogenum ZHA57, Paenibacillus castaneae ZHA88, ZHA178, ZHA296, Pseudomonas viridilivida ZHA308 and Tsukamurella paurometabola ZHA569 isolates were detected to inhibit development of $P$. capsici $L$. (Phytophthora blight of pepper) significantly $\left(\mathrm{F}_{4,84}=9,30 ; \mathrm{p}<0.05\right)$. Among these bacteria, $M$. immunogenum ZHA17, Paenibacillus castaneae ZHA212, ZHA215, B. subtilis ss subtilis ZHA287 and unidentified ZHA579 isolates were detected to inhibit $P$. capsici (Phytophthora blight of pepper) partly. Uppal et al. (2006) detected in their study that $P$. viridilivida inhibited development Verticillium wilt disease caused by Verticillium dahliae. Daafy et al. (2003) reported that $P$. viridilivida isolate was effective against potato late blight caused by Phytophthora infestans. Kim et al. (2009) reported in their study that 15 isolates of Paenibacillus polymyxa showed antimicrobial activity against $P$. capsici, which was similar to in this study. Soil borne bacteria not only inhibit development of certain plant disease agents but also increase resistance of plants. Tran et al. (2007) reported that $P$. flourescens not only inhibited infection against potato late blight caused by Phytophthora infestans, but also inhibited formation of spore structures. Zang et al. (2010) determined that certain isolates of soil borne Bacillus bacteria decreases the severity of $P$. capsici at a significant level at greenhouse conditions. It was reported in many studies that Mycobacterium immunogenum species, which display a similarity rate of $50-56 \%$ in GEN III identification, is a pathogen bacteria for people (Loots et al., 2006; Selvaraju et al., 2005; Gordon et al., 2008). However, identification of $M$. immunogenum ZHA17 and ZHA57 isolates, which were reported to inhibit development of pathogens during the inhibition studies conducted against $P$. capsici, must be supported with molecular identification methods; and it must be detected whether these isolates are pathogens for people. If they are not hazardous in terms of being human pathogen, they can be studied for biological control studies.

There are studies indicating that C-924 isolate of Tsukamurella paurometabola species shows antagonistic effect against plant pathogenic fungi and that they may be used for biological control of nematodes (Bruzos et al., 2013; Marin et al., 2013; Hernandez et al., 2008).

It is reported based on the studies conducted that induced systemic resistance (ISR) of soil borne bacteria representing various species including Pseudomonas and Bacillus encourages systemic acquired resistance (SAR) (Raupach and Kloepper 1998; Kloopper et al., 2004; Mirik, 2005; Zhang et al., 2010). It is proved via the soil borne bacteria that signal transmission in ISR is independent from salicylic acid but dependent on ethylene and jasmonic acid (Tran et al., 2007). Kone at al. (2009) treated their plants in their study with 
systemic acquired resistance (SAR) indicators including acibenzolar-S-methyl (ASM); and determined that it showed resistance in pumpkin against $P$. capsici. As a result, certain isolates, which were isolated from soil samples taken from pepper fields from the Kahramanmaras province, was determined to be effective against $P$. capsici. In future studies, effective isolates should be selected and the inhibition mechanism of soil borne bacteria against $P$. capsici and efficiency of different combinations of these bacteria against $P$. capsici must be explored, and finally the optimum combination could be determined.

\section{ACKNOWLEDGEMENT}

This work was supported by Kahramanmaraş Sütçü İmam University The Scientific Research Coordination Unit, Project number: 2014/3 16 YLS. This study was derived from master thesis of Zeynep Hümeyra ARDIÇ.

\section{Statement of Conflict of Interest}

Authors have declared no conflict of interest.

\section{Author's Contributions}

The contribution of the authors is equal.

\section{REFERENCES}

Abak K, Pitrat M 1981. Biberlerde Kök Boğazı Yanıklığı (Phytophthora capsici Leon) Hastalığına Dayanıklılık Üzerine Bir Araştırma. A.Ü.Z.F. Yıllığı 29(2-3-4):943-947.

Akgül DS, Mirik M 2008. Biocontrol of Phytophthora capsici on Pepper Plants by Bacillus megaterium Strains. Journal of Plant Pathology 90(1):29-34.

Anand R, Chanway CP 2013. Nif Gene Sequence and Arrangement in the Endophytic Diazotroph Paenibacillus polymyxa Strain P2b-2R. Biol Fertil Soils 49:965-970.

Anand R, Grayston S, Chanway C 2013. N-2-Fixation and Seedling Growth Promotion of Lodgepole Pine by Endophytic Paenibacillus polymyxa. Microb Ecol 66:369-374.

Anonymus 2008. Biolog Gen III Microplate Instruction for Use.

Aysan Y, Karatas A, Cinar O 2003. Biological Control of Bacterial Stem Rot Caused by Erwinina chrysanthemi on Tomato. Crop Protection 22:807811.

Bruzos MM, Campos JM, Chavez PC, Valdivia RM, Vazquez EP 2013. Interaction Among Tsukamurella paurometabola C-924 and Rhizobium leguminosarum biovar phaseoli $\mathrm{CFH}$ in Bean Plants. Acta Agronomica 62(1):52-58.

Daafy F, Adam L, Fernando VGD 2003. Comparative Screening of Bacteria for Biological Control of Potato Late Blight (strain US-8), Using in vitro,
Detached-leaves, and Whole-plant Testing Systems. Can J Plant Pathol 25:276-284.

Gordon T, Nadjiezko C, Galdanes K, Lewis D, Donnely $\mathrm{K}$ 2006. Mycobacterium immunogenum Causes Hypersensitivity Pneumonitis-like Pathology in Mice. Journal Inhalation Toxicology 18(6):449-456.

Guo T, Liao MD 2014. Suppression of Rhizoctonia solani and Induction of Host Plant Resistance by Paenibacillus kribbensis PS04 Towards Controlling of Rice Sheath Blight. Biocontrol Sci Technol 24:116-121.

Hernandez A, Moreira A, Pimentel E, Martinez J, Mena J, Del Toro N 2008. A Rapid Method for Estimating Viability in Desiccated Cells of the Biocontrol Agent Tsukamurella paurometabola C924. Journal of Rapid Methods \& Automation in Microbiology 16:222-229.

Jee HJ, Nam CK, Kim CH 1988. Studies and Biological Control of Phytophthora Blight of Red Pepper.1. Isolation of Antagonists and Evulation of Antagonistic Activity in vitro and in Greenhouse. Korean J Plant Pathol 4(4):305-312.

Kim SG, Khan Z, Jeon YH, Kim YH 2009. Inhibitory Effect of Paenibacillus polymyxa GBR-462 on Phytophtora capsici causing Phytophtora Blight in Chilli Pepper. Journal of Phytopathology 157(6): 329-337.

Kloepper JW, Ryu CM, Zhang SA 2004. Induced Systemic Resistance and Promotion of Plant Growth by Bacillus spp. Phytopathology 94:12591266.

Kone D, Csinos AS, Jackson KL, Ji P2009. Evaluation of Systemic Acquired Inducers for Control of Phytophthora capsici on Squash. Crop Protection 28:533-538.

Leonian LH 1922. Stem and Fruit Blight of Pepper Caused by Phytohthora capsici sp. Nov. Phytopathology 12:401-408.

Ling N, Huang Q, Guo S, Shen Q 2011. Paenibacillus polymyxa SQR-21 Systemically Affects Root Exudates of Watermelon to Decrease the Conidial Germination of Fusarium oxysporum f.sp. niveum. Plant Soil 341:485-493.

Ling N, Wang D, Zhu C, Song Y, Yu G, Ran W, Huang Q, Guo S, Shen Q 2014. Response of the Population Size and Community Structure of Paenibacillus spp. to Different Fertilization Regimes in a Longterm Experiment of Red Soil. Plant Soil 383:87-98.

Loots MAM, De Jong MD, Van Solingen D, Wetsteyn JCFM, Faber WR 2006. Chronic Leg Ulcer Caused by Mycobacterium immunogenum. Journal of Travel Medicine 12(6):347-349.

MarinM, WongI, GarciaG, MoranR, BasultoR, PimentelE, Mena J 2013. Actividad Antagónica in vitro de Tsukamurella paurometabola C-924 Frente a Fitopatógenos. Rev ProtecciónVeg 28(2):132-137.

Mirik M 2005. Biberde Bakteriyel Leke Etmeni Xanthomonas axonopodis pv. vesicatorianın 
Tanılanması ve Bitki Büyüme Düzenleyici Rizobakteriler ile Biyolojik Mücadele Olanakları. Ç.Ü. Fen Bilimleri Enstitüsü Bitki Koruma Anabilim Dalı Doktora Tezi,162 sy.

Raupach GS, Kloepper JW 1998. Mixtures of Plant Growth-Promoting Rhizobacteria Enhance Biological Control of Multiple Cucumber Pathogens. Phytopathology 88:1158-1164.

Rosyid TA, Karim R, Adzahan NM, Chazali FM 2011. Antibacterial Activity of Several Malaysian Leaves Extracts on the Spoilage Bacteria of Yellow Alkaline Noodles. African Journal of Microbiology Research 5(8):898- 904.

Selvaraju SB, Khan IUH, Yadav JS 2005. Biocidal Activity of Formaldehyde and Nonformaldehyde Biocides Toward Mycobacterium immunogenum and Pseudomonas fluorescens in Pure and Mixed Suspensions in Synthetic Metalworking Fluid and Saline.Applied And Environmental Microbiology 71(1): 542-546.
Tran H, Ficke A, Asiimwe T, Höfte M, Raaijmakers JM 2007. Role of the Cyclic Lipopeptide Massetolide A in Biological Control of Phytophthora infestans and in Colonization of Tomato Plants by Pseudomonas fluorescens. New Phytologist 175:731-742.

Tsao PH 1983. Factors Affecting Isolation and Quantitation of Phytophthora from Soil. (Phytophthora: Its Biology, Taxonomy, Ecology, and Pathology, American Phytopathological Society ST Paul, MN., USA: Ed. Erwin DC, Bartnicki-Garcia S, Tsao PH, 219-236 sn.

Uppal AK, El Hadrami A, Adam LR, Menuta M, Daafy F 2007. Pathogenic Variability of Verticillium dahliae Isolates from Patato Fields in Manitoba and Screening of Bacteria for their Biocontrol. Can J Plant Pathol 29:141-152.

Zhang S, White TL, Martinez MC, McInroy JA, Kloepper JW, Klassen W 2010. Evaluation of Plant Growth-Promoting Rhizobacteria for Control of Phytophthora Blight on Squash Under Greenhouse Conditions. Biological Control 53:129-135. 